\title{
曝気式循環施設により成層破壊されている 三春ダム貯水池内の流動構造 HYDRODYNAMIC STRUCTURE IN MIHARU RESERVOIR CAUSED BY DESTRATIFICATION SYSTEM
}

\author{
堀井貴之 ${ }^{1}$ 梅田信 2 ・佐藤洋人 1 -木村文宣 ${ }^{3}$ \\ Takayuki HORII, Makoto UMEDA, Hiroto SATO and Fuminori KIMURA \\ 1 学生会員 東北大学大学院工学研究科（干980-8502 仙台市青葉区荒巻字青葉 6-6-06） \\ 2 正会員 博士（工学）東北大学大学院工学研究科（９980-8502 仙台市青葉区荒巻字青葉 6-6-06） \\ 3 正会員 一般財団法人水源地環境センター（†102-0083 東京都千代田区麦町 2-14-2 麹町 NK ビル）
}

\begin{abstract}
Hydrodynamic structure was measured in a reservoir equipped with bubble-diffuser type destratification system. Water quality of the reservoir is much eutrophic, so that the system of destratification is operated during summer to prevent algal bloom. However, appropriate operation of the system requires substantial understanding on hydraulic structure in the reservoir. In this study, two kinds of flow measurements were conducted: vertical profile of velocity at a fixed point for two weeks during stratification season, and spatial flow pattern in the reservoir. The former elucidated three-layered structure of current which is likely to be made by not only the destratification system but also internal seiche and the seasonal stratification. The latter illustrated detailed spatial flow pattern under operation of bubble diffusers.
\end{abstract}

Key Words : Destratification system, reservoir, field measurement, flow velocity, thermal stratification, turbidity

\section{1. 序論}

ダム貯水池は，治水や水道用水の供給など利水におけ る役割を担っており, 社会基盤施設として重要なもので ある. また環境面でも，正常流量の確保により，下流河 川の生態環境が改善1)されるという効用が見込まれる. その一方で，環境的には検討するべき課題を抱えている， 最も重視される問題のうち一つは，水質である. 貯水池 の水質が悪化すると, 利水上の障害 ${ }^{2} や ，$ 貯水池および その下流における種々の環境問題（景観覀化，生態系へ の影響）を引き起こすことがある．また我が国の貯水池 の水質は, 温暖化により将来的に富栄養化が進むことが

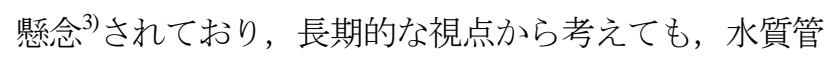
理は重要な課題である.

本研究で対象とする三春ダムは, 集水域に比較的多く の人口を抱えているため, 富栄養化現象が発生しており, 特に夏期には藍藻類の増殖によるアオコがたびたび発生 している. そのため, 貯水池にはアオコ対策として曝気 式循環施設出が設置されている。曝気式循環施設は，気 泡の浮力を利用して表層部の密度成層を破壊し, 植物プ
ランクトンを補償深度まで拡散させることにより, アオ コの発生を低減させる水質保全対策である. 既往の研究 により, 曝気循環のアオコ対策としての効果要因, 湖内 流動に関する知見 5 , 6)やモデリング技術も発達してきた が，施設の効率的な運用など，近年の差し迫ったニーズ に応えるためには，より詳細な検討が必要である.

三春ダムでは, 富栄養化現象の一つである底層の嫌気 化を防ぐため，アオコ対策のための曝気循環とは別途に， 深層曝気を実施していた。 しかしながら，深層曝気施設 と曝気式循環施設の深度方向の位置関係が近接している ことから，それぞれの効果範囲が不明確になっていた。 そこで，これらの施設の効果検証と運用の最適化を目的 に, 平成22年度から深層曝気の稼働を停止している7 。 また, 福島第一原子力発電所功比較的近い距離に位置 するため, 貯水池内の放射性セシウムの挙動に関しても 留意する必要があると考えられている. 三春ダム湖水中 の放射能濃度は，通常の測定では検出限界以下であるが， 渡邊ら ${ }^{8)}$ は, 特殊なフィルタを用いたろ過濃縮などを行 い計測をした，その結果によると，貯水池の成層化と秋 期の大循環に影響を受けたと考えられる，鉛直分布の季 


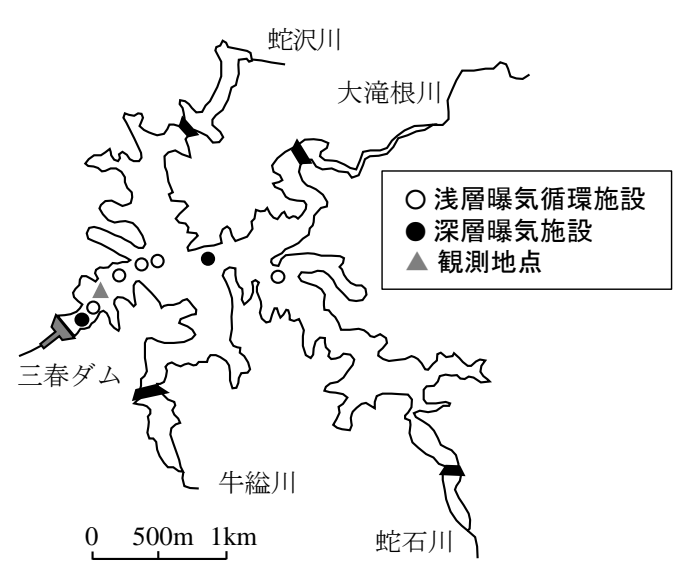

図-1 三春ダム貯水池の平面図

節変動が生じている。これらのことも含め, 貯水池内の 水理構造が，水質環境の重要な基盤要素と言え，湖水流 動に関してより緻密な検討が必要と考えられる.

本研究では，福島県の三春ダムを対象として，2011年 と2012年の夏期に，三春ダム貯水池下流部において曝気 式循環施設の影響が大きいと考えられる範囲で，水理環 境に関する現地観測を行った。この観測結果について解 析を行い，三春ダム貯水池内の水理的な特徵を把握し， 曝気循環の効果や影響に関する考察をした.

\section{2. 研究対象}

本研究では福島県三春町の阿武隈水系大滝根川上に位 置する三春ダムを対象とした。三春ダムは平成9年度に 完成した比較的新しいダムである．総貯水量は $42.8 \times$ $10^{6} \mathrm{~m}^{3}$ であり，貯水池湛水面積 $2.9 \mathrm{~km}^{2}$ である. 図-1 に三 春ダム貯水池の平面図を示す。三春ダム流入量の $85 \%$ を 大滝根川が占める。また，やつで状の形状をしているた めに水の流れが局所的に帯留しやすい貯水池であり，入 り江ではアオコの集積が顕著に見られる．現在までに利 水上の問題は発生していないが，湖内負荷の蓄積による 水質悪化が懸念されている9).

これら水質悪化の対策として，三春ダムは様々な水質 保全施設が設置されている ${ }^{10)}$. 貯水池内の水質保全施設 としては，図-1 に示すように，曝気式循環施設5台及び 深層曝気施設 2 台（ただし深層曝気は平成22年度から停 止中）が設置されている，そのほかに，流入水バイパス による流入栄養塩負荷の低減や選択取水施設による取放 水質の制御が行われている. ダム管理者からの情報によ ると，藻類増殖の顕著な夏期は，表層取水により，ダム サイトの水面近くにおける藻類の増殖や集積を妨げる運 用を，近年行っているということである。

\section{3. 観測方法}

現地観測は，曝気施設が設置されている貯水池下流部

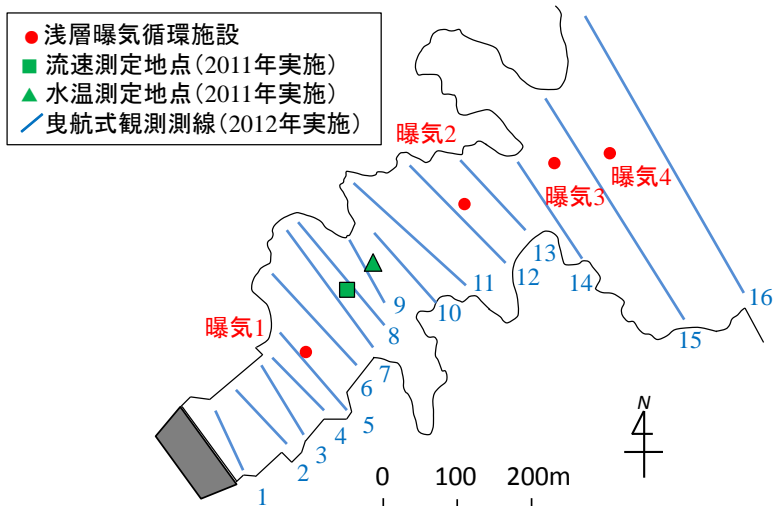

図-2 観測地点付近の平面図及び観測地点

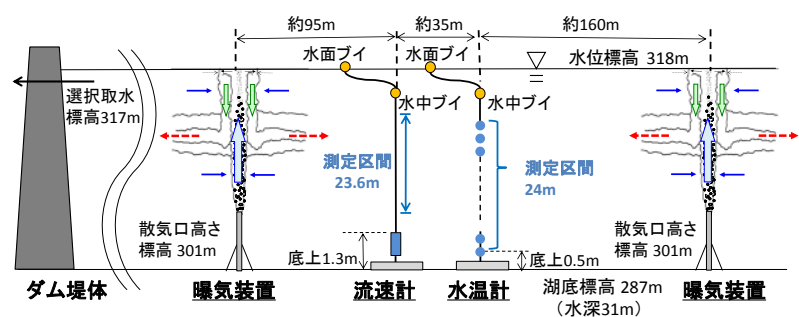

図-3 2011年の観測地点付近の縱断面模式図

において，大きく分けて二通りを実施した．１固定点に 計測器を設置して行った定点連続観測，(2)観測船を航行 して行った空間的な流動分布観測である。

\section{（1）連続観測}

三春ダムの堤体付近において，2011年7月14日から8月 1日までの約3週間の水温鉛直分布と流速鉛直分布の連続 観測を行った。また8月1日に多項目水質計による測定を 行った. 図-2 に観測地点付近の平面図, 図-3 に縦断面 模式図を示す．観測地点の決定には，曝気周辺の流動特 性5), 6)を考慮した。曝気装置による気泡噴流によって下 層の低水温水が持ち上げられる. 内部プルームと呼ばれ るこの流れが水面に衝突すると気泡は水面から抜けてい くため，連行された水は浮力を失い密度流的に潜り込む。 この下降する流れを外部プルームといい，周囲の密度が 外部プルームの水の密度と等しくなった高さで水の流れ は外側に広がっていく。この流れをイントリュージョン という。下降流（外部プルーム）が生じる範囲は，丹羽 $ら^{11)}$ によって曝気から数十 $\mathrm{m}$ 程度であることが確かめら れている。三春ダムにおいても，本研究の観測時に目視 等により概略的に確認したところ, やはり数十 $\mathrm{m}$ 程度で あった．本観測の目的としては，曝気装置から貯水池内 全体へと広がる流動（イントリュージョン領域）を把握 することであるため, 最も近傍の浅層曝気循環装置から 上流側に約 $95 \mathrm{~m}$ の距離をとり，この地点から上流側の浅 層曝気循環装置までの距離は約 $200 \mathrm{~m}$ となる地点に流速 計を設置した。水温計については, 流速計設置地点から 上流側に約 $35 \mathrm{~m}$ 離れた位置に設置した.

観測には，Nortek社のAquadopp Profilerを用いた。連続 
観測では躍層より下部を含めた流動の把握を目的として

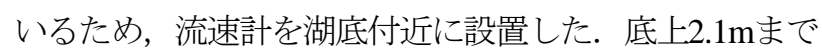
は不感帯（センサー面から計測第一層までの深さ）とな るため，図-3 内に示したように底上 $2.1 \mathrm{~m}$ (EL. 289m) の位置から水表面より $5 \mathrm{~m}$ 程深部（EL. $313 \mathrm{~m} ）$ までの $23.6 \mathrm{~m}$ の区間について, 層厚 $0.4 \mathrm{~m}$ で 60 ケ所の流速を 10 分 間隔で測定した. 通常の浅層曝気循環装置の散気口高さ は標高301mであり，測定した区間のほぼ中央に位置し ている. 今回の観測の設定による流速計の計測精度は水 平流速が $3.6 \mathrm{~cm} / \mathrm{s}$ ，鉛直流速が $1.2 \mathrm{~cm} / \mathrm{s}$ であった.

水温の観測は，Onset製Tidbit（精度 $0.2^{\circ} \mathrm{C} ）$ を水深方向 に0.5m間隔で設置した．流速計の計測区間とほぼ同程度 の計測区間として, 底上 $0.5 \mathrm{~m}$ の位置から水表面より $6 \mathrm{~m}$ 程深部までの $24 \mathrm{~m}$ の間について5分間隔で計測を行っ た.

多項目水質計による観測は，JFEアドバンテック社製 RINKO-Profilerを使用した．測定間隔を $0.1 \mathrm{~m} と し ，$ 流速 計設置地点付近おいて, 湖底から水表面までの水質（水 温，濁度，DO，クロロフィルa）の鉛直分布を計測した。

\section{（2）空間分布観測}

2012年7月 25 日に，曝気循環施設が複数設置されてい る貯水池下流部において, 小型船にSonTek社のRiver Surveyor M9を搭載して湖水流動の空間分布を観測した. 図-2 に曳航式観測区間を青線で示している. ダムサイ トからおよそ40m間隔で，16本の測線について計測を 行った. 測定区間中心部の水深が約 $32 \mathrm{~m}$ であるのに対し， 測定された水深は中心部で約 $20 \mathrm{~m} ゙$ ある。曝気装置の散 気口水深は約 $17 \mathrm{~m}$ であり, 今回の観測範囲は表層から散 気口のやや下層までとなっている，測定の際は，誤差を 抑えるために, 平均的には $0.7 \mathrm{~m} / \mathrm{s}$ 程度のできるだけ低速 で，貯水池横断方向を航行しながら，1秒間隔でデータ を取得した。 また，流速計に搭載のGPSで，測定位置も 同時に記録した. 今回の観測に用いたADPの特徵は，水 深や湖底の形状により, 計測層厚, セル数, 最浅測定深 度を計測中に自動設定することである. 湖岸付近の浅い 位置では計測層厚が最小 $0.02 \mathrm{~m}$ と小さくなるのに対し, 水深の大きい湖の中心部では計測層厚 $2 \mathrm{~m}$ と測定地点に より大きく異なる，そこで，データ整理上は，得られた

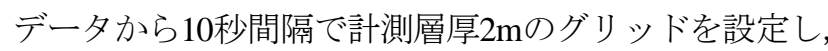
中に含まれる流速の平均值を算出した。 したがって, 後 に示寸流速分布の整理結果では，各点で少なくとも10 データの平均をとっていることになる．また，流速計の 発信機の取り付け角は中心から 25 度であり, 超音波ビー 么の水平的な拡がりは，水深 $20 \mathrm{~m}$ でも流速計から半径 $10 \mathrm{~m}$ 未満である. 一方, 曝気による気泡噴流の水平範囲 は，直径が5m程であることを観測時の目視計測で確認 している. また観測時の航路は，やはり目視であるが気 泡噴流から少なくとも $10 \mathrm{~m}$ 以上は距離をとっている.こ のようなことから，本測定結果は曝気で出ている気泡の

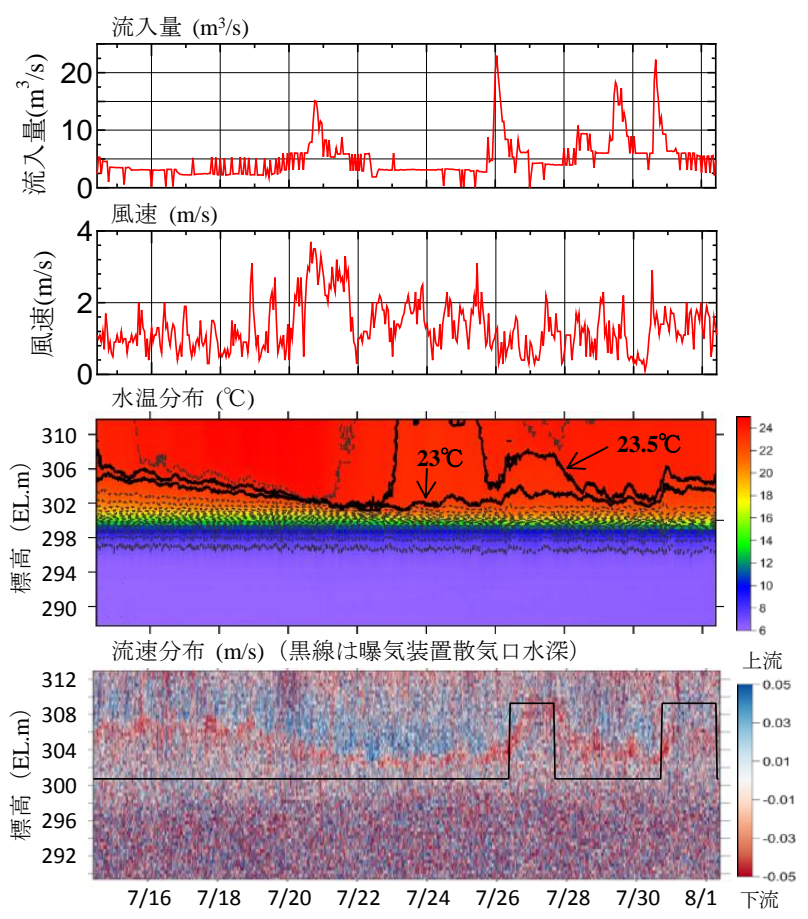

\section{図-4 2011年夏期の観測結果（上から貯水池流入量, 風速,} 水温分布，流速分布の各時系列)

直接的な影響を受けていないと考えられる. また，貯水 池下流部数地点において，2011年度と同様に多項目水質 計による測定も実施した.

\section{4. 観測結果と解析}

\section{（1）連続観測}

観測時の貯水池状況として流入量, 風速, また, 観測 結果として水温分布，流速分布を図-4 に示寸．流速分 布は, 曝気装置から貯水池縦断方向の流れを把握するた めに貯水池の上下流方向（概衩北東一南西方向）の成分 を抽出して整理している．また，流速分布内に，曝気装 置の散気口水深を併せて示している.

水温分布から, 曝気循環の効果により標高300m付近 に強い水温躍層の形成が確認できる．流速分布には，概 ね標高 $312 \mathrm{~m}$ から $302 \mathrm{~m}$ の間で比較的濃く色で示されてい る下流向きの流速の領域が, 厚さ $2 \mathrm{~m}$ 程度で存在し, 上 下に移動する様子がみられる.この部分が曝気循環によ るイントリュージョン ${ }^{5}$ に対応寸ると考えられる. なお, 図-4 上側に示寸ように, 測定期間中の風速は概ね $2 \mathrm{~m} / \mathrm{s}$ 以下と小さく, 湖水流動への影響は小さかったと推測さ れる. $23^{\circ} \mathrm{C}$ と $23.5^{\circ} \mathrm{C}$ 等温線を水温分布中に強調して示 したが，この等温線とイントリュージョンの深度変化に， ある程度対応が見られる。 また，この等温線の深度は， 日周期的に上下変動している. この動きは, 表層水温の 日周変化によって, 曝気周囲の外部プルームおよびイン トリュージョンの水温（密度）もわずかであるが変化す ること晞に起因する現象と考えられる. 本観測期間中の 


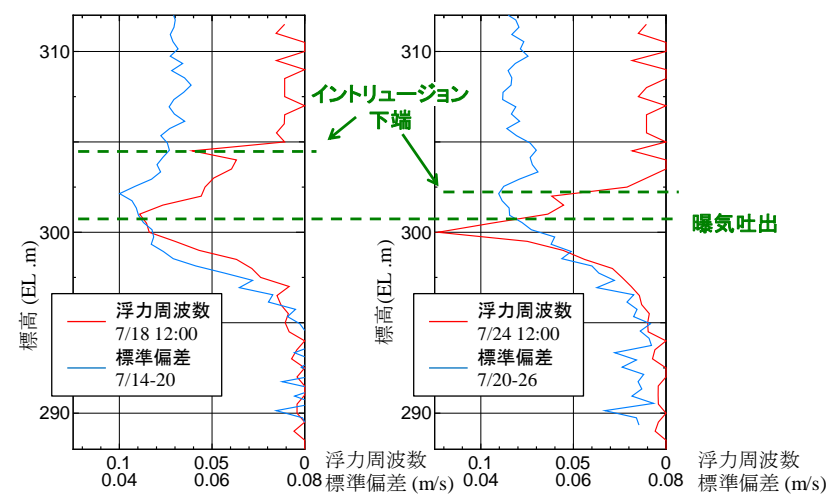

図-5 2期間（左図：観測期間初期，右図 : 観測期間中期）に おける成層強度（浮力周波数）と流速変動（標準偏差））

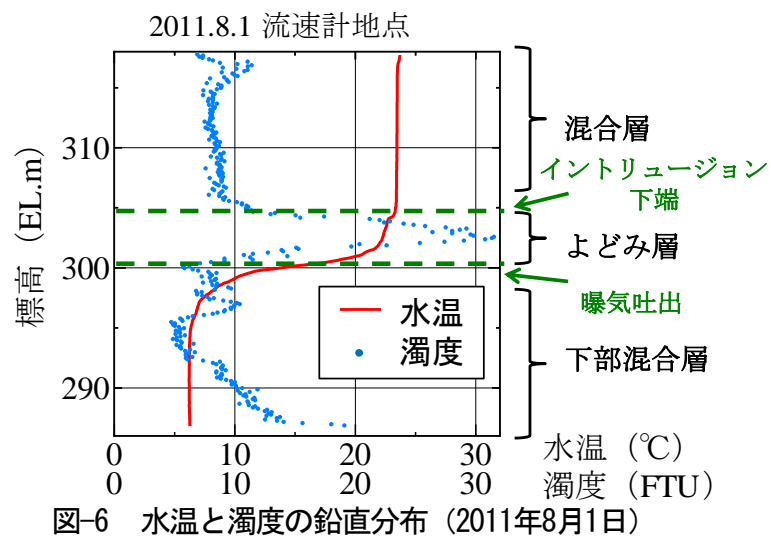

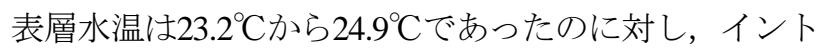
リュージョンと推測される水温が $23^{\circ} \mathrm{C}$ から $23.5^{\circ} \mathrm{C}$ 程度で ある。このようなごくわずかな水温差に対し，気象条件 や流入の条件に応じてイントリュージョンの深度や強度 に変化が現れていると考えられる。

7月26日および28日から31日には小出水があり，流入 量が増加した。この期間に，流速分布と等温線深度から 確認されるイントリュージョン深度にも変動が見られる。 ただし，7月26日からの約1日のイントリュージョンの大 幅な上昇は，出水時の濁水対応として曝気装置の散気口 の上昇によるものである可能性が高い.

水温躍層にあたる標高 $302 \mathrm{~m}$ から298mの間の流速が小 さいのに対し，標高298m以下の躍層以深では，（図中 の色の濃淡変化が大きいことから）躍層付近と比較して 流速変動が大きく, 躍層以深でもやや大きな流動が生じ ている可能性がある.イントリュージョンの深度が比較 的安定している7月14日から20日と20日から26日の2期間 について，各水深における流速の時間変化の標準偏差を 計算した。この流速の標準偏差は，乱れに対応するよう なものを想定している．ただし，本研究で用いた流速計 では，時空間的な精度が乱流計測に十分ではないため， このような指標により考慮した。また，7月18日正午と 24 日正午の水温分布から，各期間の代表浮力周波数を算 出した. 図-5 に浮力周波数と流速の標準偏差の比較を

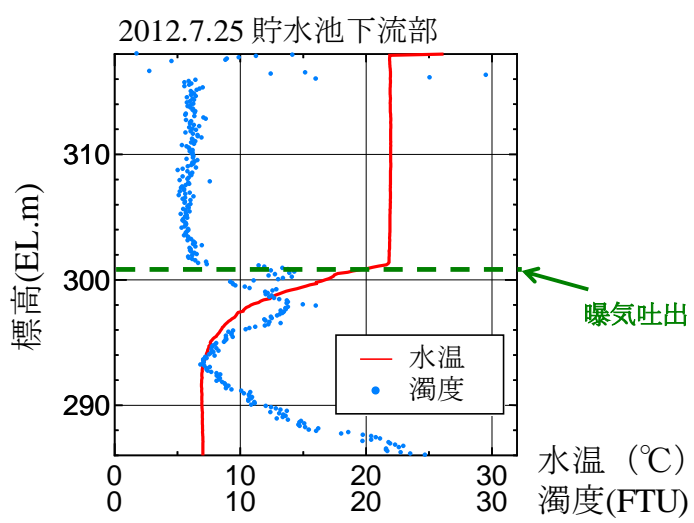

図-7 水温と濁度の鉛直分布（2012年7月25日）

示す. 浮力周波数Nは次式で表される密度成層安定度の 指標である.

$$
N=\left(\frac{g}{\rho} \frac{\partial \rho}{\partial z}\right)^{1 / 2}
$$

ここで， $g$ : 重力加速度， $\rho:$ 水の密度， $z$ : 水深である. この図では，成層強度と流速変動の関係が見やすいよう に，浮力周波数の正負の向きを逆にしている．特に躍層 以深で，成層安定度と流速変動に負の相関が高いことが 確認できる．底層部の流動要因としては，横山ら ${ }^{12)}$ が 指摘している内部静振の影響が考えられる.

また，図-4 下段の流速分布から読み取れるイント リュージョンの深度は，標高306m付近（7月14日から20 日）あるいは標高304m付近（7月20日から26日）である. これに概ね対応して，図-5 に示したように浮力周波数 の極大值が見られる，これに加え，曝気吐出水深付近に は，浮力周波数のピークが出現している．一方，流速変 動（標準偏差）は，これら2水深の間で緩やかな谷を 持っている. このような特性量の分布と，図-6に示す 水温と濁度の鉛直分布を対比すると，貯水池内は水理的 な3層構造になっていることが読み取れる。つまり，水 面からイントリュージョンの下端までの範囲は，（上部） 混合層となっている. 続いて, イントリュージョンから 曝気吐出口までの中間層は，濁度が高く流速変動が小さ い「よどみ層」が形成されている。 さらに曝気吐出口

(三水温躍層) 以深には, 流速変動の大きい下部混合層 が生じている.

\section{（2）空間分布観測}

水温と濁度の鉛直分布を，流動計測時の湖内条件とし て図-7 に示す. 曝気吐出口水深である水深 $17 \mathrm{~m}$ 付近で 水温躍層が生じ，吐出口以浅では混合により水温が一定 となっていることから，曝気装置が効果的に作用してい ることが確認できる。なお，観測時の直近の出水が7月7 日で20日程度間があったため，図-6にあったような吐 出口上層での濁度のピークが観測されなかったと考えら れる。

図-8 は，最も流れの特徵が現れていた水深 $2 \mathrm{~m} と 12 \mathrm{~m}$ 

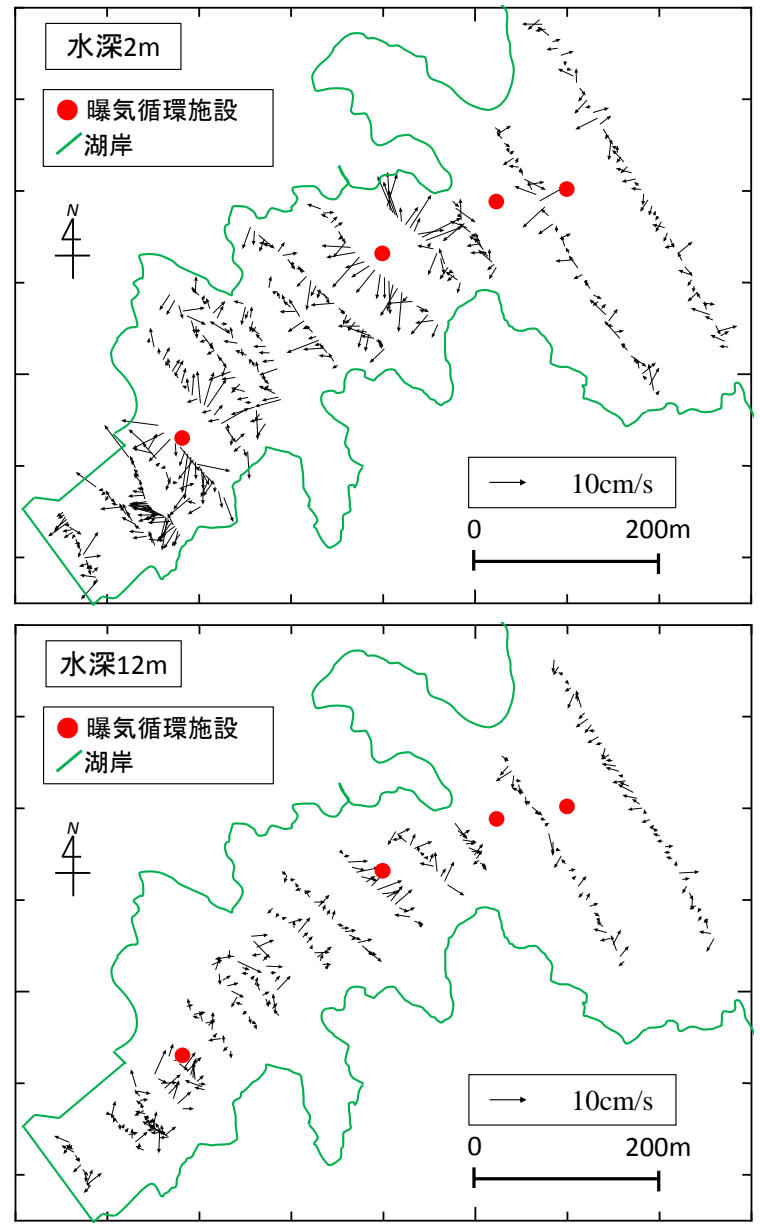

図-8＼cjkstart水深2，12mlにおける平面流速分布

における水平方向成分の流速データから作成したベクト ル図である. 整理結果のうちでは水面の最近傍層となる 水深 $2 \mathrm{~m}$ の図によると, 曝気 1 と曝気 2 のどちらも, 近傍 の測線で暴気施設を中心とした放射状の流れが見られる。 一方で，さらに外側の測線では，そのような明確な流れ は消えている，このことから，曝気による上昇，下降流 （内部，外部プルーム）の範囲は，直径 $100 \mathrm{~m}$ 程度であ

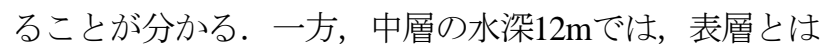
異なり，概ね上流側一向からような流動が見られる。 な お，三春ダム管理所の計測によると，本観測中の平均風 速は $1 \mathrm{~m} / \mathrm{s}$ 未満とほぼ無風であったことから，風の影響は ほぼないものと考えられる。

図-9 には，各測線で水深 $2 \mathrm{~m}$ 毎に断面通過流量を算出 した結果を示した. 図-8 においてもある程度傾向が見 えていたように，表層で下流向きの流れが卓越し，中層 では逆に上流向きになっている，下流向きの流れは，水 面下から概水水深 $6 \mathrm{~m}$ 程度までの範囲になっている. 寸 でに述べたように，三春ダムの夏期には水質対策として 表層放流を行っており, 取水口の水深は約 $4 \mathrm{~m} に$ 位置し ている，流動層の厚さがあることを考えると，表層の流 れは取水に影響されたものであると推測される.

連続観測の結果（図-4，2011年実施）と対比すると, 鉛直的な流動構造は，少なくとも定性的には，対応が取
れていると考えられる. 2011年の観測結果によると, イ ントリュージョンの流れは, 水温躍層の上端に位置して おり，それより上側では上流向きの流れとなっていた. 2012年の曳航観測では，イントリュージョンは直接的に 確認できなかった（イントリュージョンの層厚が $2 \mathrm{~m}$ 程 度であり，測定解像度が十分ではなかったため) が，水 温躍層の数 $\mathrm{m}$ 上側で上流への流れが卓越していた. なお, 図-6 と図-7 を比較すると，2011年は躍層上端付近の水 温分布が比較的なめらかであるのに対して，2012年は曝 気吐出水深で急変する形だった. したがって，2012年の イントリュージョンは, 曝気吐出高にあたるEL301m （水深約18m）に生じていたと推測される.

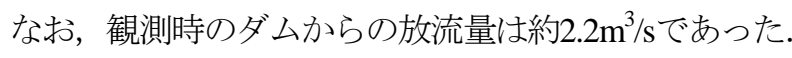
これと比較すると, 図-9 の結果は, 全体的に流動量が かなり大きい. その理由に, 流量の推定精度も考え得る が, 曝気循環により誘起される循環流量が大きいことが 第一の理由として考えられる. 三春ダムと同様に, 複数 の曝気施設が稼働しているダムにおける既往研究5)では, ダム流入量の数倍程度の断面流量が観測されていた。 ま

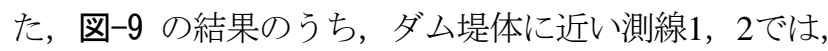
表層流量が，放流量に比較的近い值になっている. 一方， それより上流の測線で，流量が増大している．このこと も，曝気循環によって引き起こされている湖内循環の大 きさを示唆するものと考えられる.

\section{5. 結論}

本研究では，三春ダムを対象として，アオコ対策とし て設置されている曝気式循環施設による流動の影響を含 めた, 湖内の水環境に関する現地観測を実施した。 本研 究で実施した2力年 (2通り) の流動観測では, 三春ダム における湖内流動の全貌を捉えきれたとは言えない面も ある. しかしながら，両者をあわせて考察すると，次の ようなことが結論づけられる.

1）設置型観測による連測的な水温と流動の鉛直分布 計測により，三層構造の流動環境が確認された。 これは, 水温成層による表水層, 水温躍層, 深水層の三つに対応 するものである. 成層安定度と流速の変動量に負の相関 が生じていることが確認された，流動が成層構造を持つ 要因としては, 密度成層自体に加え, 曝気による流動

（上層におけるイントリュージョン流れ）および内部セ イシュ（主に下層部での流速変動）があると推測される. また, 水温躍層の上端付近は, 成層安定度が高く, 流速 変動も極小を取っていることから，濁水が滞留しやすい 構造が形成されていた.

2) 流速の鉛直分布の連続計測結果では，曝気や水面 から伝わる擾乱など，水温躍層以浅で発生する流動の影 響が小さいと考えられる深層においても，比較的大きな 流速変動が観測された. 具体的なメカニズムは十分に解 
流量 $\left[\mathrm{m}^{3} / \mathrm{s}\right] \quad$ 流量 $\left[\mathrm{m}^{3} / \mathrm{s}\right] \quad$ 流量 $\left[\mathrm{m}^{3} / \mathrm{s}\right] \quad$ 流量 $\left[\mathrm{m}^{3} / \mathrm{s}\right] \quad$ 流量 $\left[\mathrm{m}^{3} / \mathrm{s}\right] \quad$ 流量 $\left[\mathrm{m}^{3} / \mathrm{s}\right] \quad$ 流量 $\left[\mathrm{m}^{3} / \mathrm{s}\right] \quad$ 流量 $\left[\mathrm{m}^{3} / \mathrm{s}\right]$
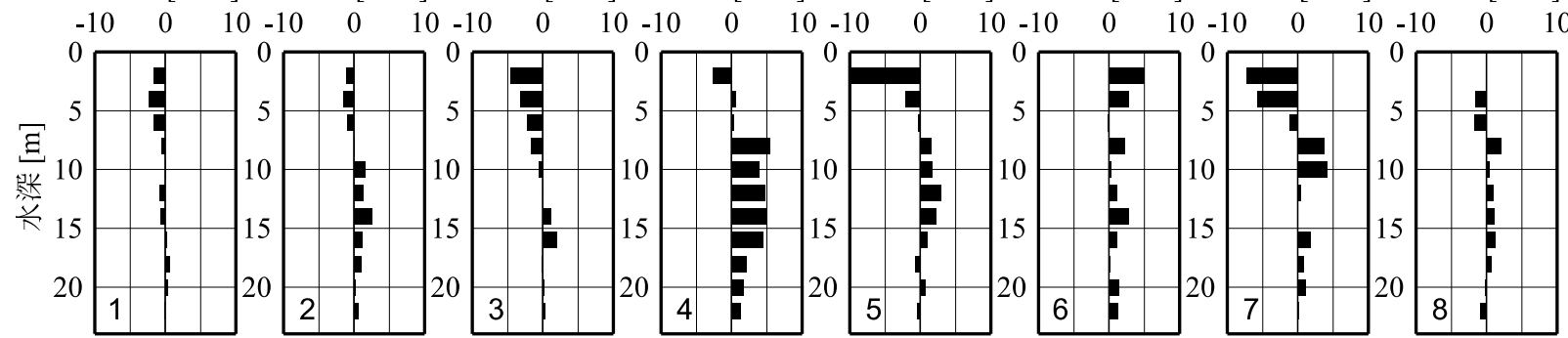

流量 $\left[\mathrm{m}^{3} / \mathrm{s}\right] \quad$ 流量 $\left[\mathrm{m}^{3} / \mathrm{s}\right] \quad$ 流量 $\left[\mathrm{m}^{3} / \mathrm{s}\right] \quad$ 流量 $\left[\mathrm{m}^{3} / \mathrm{s}\right] \quad$ 流量 $\left[\mathrm{m}^{3} / \mathrm{s}\right] \quad$ 流量 $\left[\mathrm{m}^{3} / \mathrm{s}\right] \quad$ 流量 $\left[\mathrm{m}^{3} / \mathrm{s}\right] \quad$ 流量 $\left[\mathrm{m}^{3} / \mathrm{s}\right]$
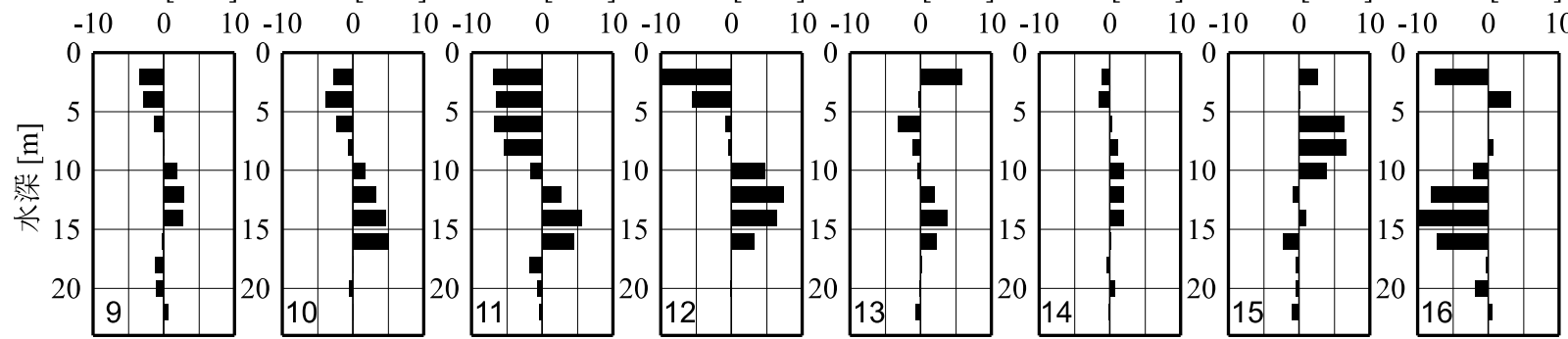

図-9＼cjkstart各測線における層別通過流量（負=下流向き，正=上流向き．各図の左下の数值か測線番号を示す）

明できなかったが，深層の嫌気化解消のための対策検討 に活用可能な知見であると考えられる.

3) 曳航式観測により，曝気式循環施設が複数ある三 春貯水池内での空間的な流動構造を捉えることができた この結果から横断面内の通過流量を推定したところ，流 入量や放流量と比べてかなり大きな流動量が推定された 流量の推定誤差も含まれていようが，既往研究における 知見と同様に曝気循環により誘起される流量はかなり大 きいことが推測される．また，鉛直的な流動構造の形成 に対しては，ダムからの取水深度の影響が大きいと考え られる. したがって，選択取水と曝気循環の両者のバラ ンスを考えた運用が，このような流動を活用した水質対 策の効果を大きく左右する可能性がある.

謝辞 : 本研究は水源地生態研究会の援助を受けた。 また JSPS科研費25289151の支援を受けた。現地観測に際して, 国土交通省東北地方整備局三春ダム管理所にご協力頂い た．YSIナノテックの中田正人博士には，2012年の流速 計測の際にご助力頂いた．記して謝意を表する.

\section{参考文献}

1) 松根駿太郎，梅田信，田中仁，佐々木幹夫：十三湖におけ る汽水環境の長期的な変化要因検討, 土木学会論文集 $\mathrm{B} 1$ (水工学)，Vol.69, No. 4, pp. I_1507-I_1512, 2013.

2) Thuan D.H., Umeda M, Matsukawa M. and Tanaka H.: Prediction model of taste-and-odor events in Kamafusa Reservoir, J. Japan Soc. Civil Eng., Ser. B1, Vol. 68, No. 4, pp. I_289-I-294, 2012.

3) 梅田信, 落合雄太 : 気候变動による国内のダム湖水質への 影響評価，土木学会論文集G（環境），Vol.68，No.5，pp.
I_127-I_135, 2012.

4) 関根秀明, 吉田延雄，梅田信，浅枝隆 : 曝気式循環施設の 理論とその効果に関する考え方，ダム工学，第13巻，pp. 518, 2003.

5) 梅田信，宮崎貴紅子，富岡誠司：曝気式循環施設により

生じる貯水池内流動の現地観測，土木学会論文集，No. 775, pp55-68, 2004.

6) 豊島靖, 天野邦彦, 田中康泰 : ダム貯水池における曝気循 環による成層破壊状況の現地観測と評価，水工学論文集， 第 47 巻, pp.1243-1248, 2003.

7) 木村文宣，金山拓広，田中靖，高橋定雄 : 深層曝気施設の 停止が深層水塊一与える影響一三春ダムの事例（中間報告） 一，ダム水源地環境技術研究所所報，pp3-11，2011.

8) 渡邊隆宏, 中野和典, 佐藤洋一, 藤田豊, 長林久夫 : 成層 期・非成層期の湖沼における検出限界領域の放射性 $\mathrm{Cs}$ の実 態調查，土木学会東北支部技術研究発表会，VII-43，2013.

9) 梅田信, 柴田光彦, 牛島健, 田中仁 : 三春ダムの植物プラ ンクトンと濁質堆積を中心とした物質循環解析, 環境工学 研究論文集，第47巻，pp. 175-183, 2010.

10）清水俊昭, 矢沢賢一, 丹羽 薰: 三春ダムさくら湖の水質 保全対策，ダム技術，No. 143，pp.71 - 81，1998.

11）丹羽薰，久納誠，大西実，山下芳浩 : 貯水池流動制御によ る水質保全対策，水工学論文集，第37巻，pp.271-276， 1993.

12）横山勝英, 新谷哲也 : ダム貯水池の内部静振と定常的往復 流のメカニズムに関する研究，水工学論文集，第50巻, pp1273-1278, 2006.

(2013. 9. 30受付) 